\title{
ADVANCED AGE AS A MITIGATING FACTOR
}

\section{Introduction}

\begin{abstract}
"Before a judicial officer imposes sentence on the offender in any given case, he first has to determine which sentences may be imposed ... The court also has to collect all information that may be relevant to the determination of a suitable sentence. Thereafter, the court has to exercise its sentencing discretion to choose the most appropriate sentence ..." (Terblanche A Guide to Sentencing in South Africa 2ed (2007) 137).
\end{abstract}

The sentencing of an offender is not determined in a vacuum. Certain guidelines and principles have been developed that should be applied in every case: the circumstances of the case; the severity of the crime; mitigating and aggravating factors regarding the offender; the interests of society; and the purposes of sentencing specifically deterrence, prevention, rehabilitation and retribution, as well as mercy (Terblanche 137-138; and see also Van der Merwe Sentencing 6ed (1998, loose-leaf) Chapter 3).

The focus of this note is only on a single aspect of the sentencing equation, specifically the extent to which the advanced age of the offender constitutes a possible mitigating factor. Although much has been written regarding youthful offenders, very little jurisprudence exists on the impact of age on persons on the opposite side of the age spectrum. This can be partly attributed to the fact that the elderly in general commit fewer crimes and that there are fewer appeals noted and reported on as age has been taken into consideration during sentencing.

The note commences with an overview of the common law, proceeds to a discussion of the South African sources and concludes with a brief comparison with the approach adopted in the Zimbabwean, English and Australian jurisdictions with regard to sentencing older offenders.

\section{Roman-Dutch sources}

Carpzovius wrote in detail in this regard in his Verhandeling der Lyfstraffelyke Misdaden en haare Berechtinge (translated by Van Hogendorp Vol II 2ed (1772) Chapter 136 "Van de verlichtinge der straffe in oude Mannen" (regarding mitigation of punishment for older persons)), noting that there was agreement amongst legal experts there must be mitigation ("verlichting") of punishment for older persons (in the same way that minors and "onhuw-baren" must be punished more lightly), because of their lack of judgment (I-II). However, he points out that most older persons (of 70 years or older) are both physically and mentally strong of body, and therefore it could be argued that their offences should be punished more heavily, as 
they know better than to offend and the reason for mitigation of punishment does not exist in such cases, namely the alienation of the mind resulting from severe old age (III; XIV). Noting the various distinctions drawn by other writers (IV), Carpzovius articulates the legal principle that old age per se never excuses a person from punishment $(\mathrm{V}$; he argues that a person who has the capacity to make a donation or a will can be said to also have criminal capacity $(X)$ ), but only when as a result of advanced age mental feebleness ensues (XV). The type of punishment meted out on an elderly person should take into account the physical frailty of such a person (XIXII). He further notes the difference in opinion in relation to when old age commences, opining that this matter is best left to the discretion of the judge $(\mathrm{VI})$.

Voet notes briefly that with old persons it would seem fair that a corporal punishment ought to be mitigated (Voet XLVIII 197 (The Selective Voet being on the Commentary on the Pandects [Paris Edition of 1829] by Johannes Voet and the Supplement to that work by Van der Linden, translated by Gane Vol 7 (1957) 510)). Further, Voet states in similar vein that tortures were not to be administered to old men with the same severity as others (Voet XLVIII 19 7).

Van der Linden 227 argues that the age of a criminal is in itself no reason for the mitigation of his sentence and that the elderly ought to be able to judge the morality of their acts more strictly than young people. "Nevertheless, the advanced years of the criminal, and the infirmities attendant thereon, should very much be taken into consideration in determining the nature of the punishments; and the punishment is therefore frequently limited to confinement in a penitentiary" (Institutes of Holland or Manual of Law, Practice and Mercantile Law, translated from the original Dutch by Juta 4ed (1904) 195-6).

These writings should be viewed in the context of a penal regime where other forms of bodily punishment were still available to the judiciary: lashings, chopping off of limbs, torture and death. Although these forms of punishment are no longer available, the principles may be considered within a current context.

\section{South African law}

South African jurisprudence accepts mero motu that once an offender has reached an advanced age, it may be regarded as a mitigating factor in the sentencing of such an offender (Terblanche 197). Although various cases refer to old age as a mitigating factor ( $S$ v Munyai 19931 SACR $252(A)$; $S$ $v$ Du Toit 19793 SA 846 (A); S v Heller 19712 SA 29 (A) and the summary in Rabie et al Punishment. An Introduction to Principles 5ed (1994); $S \mathrm{v}$ Tshatsha [2007] JOL 19598 (Ck); Mfengu v S [2005] JOL 14813 (E); Mgudu v S [2002] JOL 10060 (Tk); S v Makua 19931 SACR 160 (T); and S v Berliner 19672 SA 193 (A)), only one Supreme Court of Appeal case contains any discussion of the issue: $S v \operatorname{Zinn}(19692$ SA 537 (A)). Van der Merwe (5-26A) also refers to two unreported cases: Fouche (who was 68 
years old) found guilty of theft from a church. She received a three-year suspended sentence for four years because of her age and ill health. Similarly, Crotz (who was 72 years old) spent two nights in prison for contempt of court arising from her refusal to pay the arrears on her water and rent bill. These two unreported cases are disregarded for the purposes of the present discussion.

All these cases are ad idem that old age does not exclude criminal liability, but can serve as a mitigating factor during sentencing notwithstanding the argument that with the elderly having greater experience of life, one would expect potentially greater awareness of the consequences of their actions.

The obvious question that springs to mind is at what age a person would be regarded as elderly. Carpzovius (VI) refers to the various opinions at the time, ranging from 50 to 70 , although he prefers that the decision should be made by the judge. His opinion was noted with approval in $S v$ Zinn (supra 541h-542a) and it is submitted that this is the correct approach. It should be noted that the South African reported judgments seem to regard a person as elderly from about 58 , although that would depend on the offender before the court, especially since old age is often accompanied by another mitigating factor, namely illness or ill health (See Du Toit, Zinn, Berliner, Mfengu and Mgudu cases supra).

It has been said that the rationale for the reduction in sentence is compassion. It "evokes a note of compassion in considering the bleak recompense of imprisonment in the afternoon of his years" ( $S v$ Heller supra 55C-D). Furthermore, old age can sometimes be seen as a second childhood, a time when some elderly can become less responsible. Added hereto, they are more sensitive to some forms of punishment, especially imprisonment (Van der Merwe 5-26). Van der Merwe notes that "this factor really means that the sensitivity of the offender to punishment is higher, that he would suffer more given a specific quantum of punishment, and that imprisonment for a certain period might really turn out to be life imprisonment" (5-26A), although the courts have warned that it should guard against misplaced pity ( $S$ v Munyai supra 255i-j).

The mitigation of a sentence for imprisonment especially is based on compassion coupled with the community expectation that old people would be treated with sympathy ( $S \vee$ Munyai supra 255h-i; and Van der Merwe 526)). The purpose of a sentence is not to destroy the offender completely ( $S$ $v$ Zinn supra 541B-C) and the period of imprisonment would not offer a person of advanced age a chance to reform and begin his life anew ( $S v$ Zinn supra 541B-C).

It is, however, no guarantee that old age would lead to the mitigation of a sentence as seen from two of the nine South African reported cases. In Tshatsha particularly the age of the offender (59) was outweighed by the horrendousness of the crime committed - the rape of a 6-year-old girl.

If one considers the other available sentencing options, it is noteworthy that a warning or a monetary fine is not generally influenced by the age of 
the offender. And, although no reported case is available on this point, it is submitted that, when assessing the possibility of imprisonment, correctional supervision could be an ideal possibility for the elderly (in this regard see Terblanche 279ff). With house arrest coupled with community service, the fears of incarceration are negated.

\title{
4 Foreign jurisdictions: Zimbabwean, English and Australian Law
}

\begin{abstract}
"The significance of old age as a mitigatory factor, particularly when combined with ill health, is that it constitutes a basis on which the court, in the exercise of mercy, may impose a sentence significantly shorter than otherwise might be the case" ( $S$ v Henderson [2005] WASCA 89 par 23; and $S$ v Tasmania [2007] 173 A Crim R 492 par 13, quoting from Smith $v$ The Queen (unreported, Court of Criminal Appeal, WA, Library No 940285, 2 June 1994)).
\end{abstract}

Old age is regarded as a mitigating factor during the sentencing phase in various jurisdictions, including Zimbabwe, England and Australia. The legal principles in this regard are almost identical.

The basic rule is that advanced age can be regarded as a mitigatory factor when sentencing an offender (Zimbabwe: Feltoe $A$ Guide to Sentencing in Zimbabwe (1990) 123 with reference to Kambarami HS-1382; and see also $S v$ Banana [1999] JOL $4730(\mathrm{ZH})$; England: $R v$ John Francis C [1993] 14 Cr App R (S) 562; $R$ v Fontes [2006] 1 Cr. App. R. (S.) 76 par 13; $R$ v Rahmi [2002] EWCA Crim 928 par 6; Thomas Principles of Sentencing (1979) 196 and the cases referred to; Walker Sentencing. Theory, Law and Practice (1985) 51; Ashworth Sentencing and Criminal Justice (2005) 176; Australia: S v Tasmania [2007] 173 A Crim R 492; R v Wacyk (1996) 66 SASR 530 537; Daunton-Fear Sentencing in South Australia (1980) 66; and Fox and Freiberg Sentencing: State and Federal Law in Victoria (1985) par 11.408).

The basis for the principle is compassion and mercy (Zimbabwe: Feltoe 124; England: Thomas 196; and Australia: $S$ v Tasmania supra par 13). In Zimbabwe the courts have known to go further as it has been noted that the courts would rather err on the side of leniency when sentencing an elder (Feltoe 124). The relevance of mitigation increases with old age especially if it is combined with another mitigating factor such as poor health and a shortened life expectancy (Zimbabwe: Feltoe 124; England: Walker (1985) 51 and Australia: $S$ v Henderson par 23).

With regard to deterring the elderly from offending, there is generally no need for such deterrence as there are very few potential offenders (Zimbabwe: Feltoe 125; England: Ashworth Sentencing and Penal Policy (1983) 279). In Australia maturity alone may be mitigating depending on the circumstances of the case, as long as it does not downgrade the seriousness of the offence to the detriment of the general deterrence objective ( $S \vee$ Braham (1994) 116 FLR 38 43). The argument is that to imprison an elderly person for retributive purposes would be pointless and 
the concept of special deterrence would be irrelevant (Fox and Freiburg par 11.408). The court cannot overlook the fact that each year of the sentence represents a substantial portion of the period of life left to the offender ( $S v$ Tasmania supra par 14 with reference to $R v$ Hunter (1984) 36 SASR 101 103; Kaye $v$ The Queen [2004] WASCA 227 par 21; and Braham supra 41) and as such mercy is afforded to the elder offender (Braham supra 51).

There is no specific age fixed upon which a person is regarded as elderly (Zimbabwe: Feltoe 123; England: Walker (1985) 51; and see also Walker Aggravation, Mitigation and Mercy in English Criminal Justice (1999) 150). The length of one's life is in itself no longer a reliable measure as to how a person is affected by the process of aging (Leavitt "Proposal for Senior Offender Law" (1999) 19 Pace Law Review 293 312). It is submitted that McLure J's statement in Kaye $v$ Queen (supra par 65) provides an accurate synopsis of the legal position:

"What is 'old age' can change over time as the average lifespan increases
and may vary according to the particular circumstances of the offender,
including his or her mental and physical health and lifestyle."

Old age is of special importance when deciding whether the offender should be imprisoned, as the effects of prison are especially harsh on the elderly, difficult to adjust to or tolerate. Imprisonment for the elderly raises certain practical problems for the prison services. Three issues should be noted: it is more costly to incarcerate the elderly, mainly as a result of increased health problems, victimisation. The fear of victimisation is a problem and with longer-term confinement the elderly may become difficult to decarcerate because of institutional dependency prompted by the longer separation from society (Adams "The Intersection of Elder Law and Criminal Law: More Traffic Than One Might Assume" (2001) 30 Stetson Law Review 1331 1347-1348; and see also Leavitt (1999) Pace Law Review 314).

In general, old age would thus impact on the length of the prison sentence (Zimbabwe: Feltoe 124-125 with reference to Andrew 19831 ZLR $289(\mathrm{HH})$ and Australia: $S v$ Tasmania supra par 14 with reference to $R v$ Hunter supra 103; Kaye $v$ The Queen supra par 21; and Braham supra 41) and as such mercy is afforded to the elder offender (Braham supra 51). In English law emphasis is placed on the principle of equal impact. It is appreciated that the same penalty would have a radically different effect on various offenders. As imprisonment of an elderly offender would cause greater hardship than to a younger person it strikes a cord of injustice and as such the proportionality of the sentence should be considered within the "circumstances influencing sensibility" - one of which is age. This would be a ground for a shorter custodial sentence (Ashworth (1983) 274, 276; Thomas 196). The penalty is adjusted to take into account the character of the particular circumstances: "the aim would not be equity mitigation based on compassion and quasi-retributive reasons, but rather making adjustments in sentence to deal with certain foreseeable differential impacts" (Von Hirsch and Ashworth Proportionate Sentencing. Exploring the Principles (2005) 176. This construction is not without controversy - see the 
debate in Easton "Dangerous Waters: Taking Account of Impact in Sentencing" (2008) Criminal Law Review 105 115; Piper "Should Impact Constitute Mitigation: Structured Discretion versus Mercy" (2007) Criminal Law Review 141; Ashworth (2005) 176; and Ashworth (1983) 278-9. For an empirical study of the sentencing of the elderly in Pennsylvania, see Steffensmeier and Motivans "Older Men and Older Women in the Arms of Criminal Law: Offending Patterns and Sentencing Outcomes" (2000) Journal of Gerontology 55B(3) S141).

Old age is, however, no guarantee to be spared imprisonment as the final decision depends on the various circumstances of the matter, especially the seriousness of the offence. In itself, advanced age cannot justify the imposition of an non-custodial sentence, and should not lead to an unacceptably insubstantial sentence (Zimbabwe: Feltoe 124; England: Thomas 196; $R$ v John Francis $C$ supra; $R v$ Rahmi supra; and Australia: $R$ $v$ Cumberbatch 144 A Crim R 253 par 12; $R$ v Braham supra 50-51; and $S v$ Tasmania supra par 15 and cases cited there).

There is some authority in both England and Australia that old age may be a factor in deciding whether the offender must be prosecuted, especially for lesser offences. Ashworth argues that for crimes like shoplifting prosecution often does not follow because of the mental and emotional stress it causes and some elderly offenders have been known to commit suicide (Ashworth (1983) 276-277). Fox and Freiberg refer to the Australian case of Cobiac v Liddy (1969) 119 CLR 257, where the court found the charge of driving under the influence proved against the 72-year-old offender, but dismissed it without recording a conviction because of the age of the offender (Fox and Freiberg 11.408).

\section{Conclusion}

"Old men are twice children" - Greek proverb

The effect of aging on the capacity of the individual is an issue which spans human history. It follows that old age has been regarded as a miti-gatory factor for centuries. For example, during the Ch'ing Dynasty in China (16441911), a very old person who committed a capital offence could obtain release through monetary redemption (Ornduff "Releasing the Elderly Inmate: A Solution to Prison Overcrowding" (1996) Elder Law Review 173 189). This accords with the approach of Carpzovius: those who are worn out by old age must be pardoned (XVII). Furthermore, in sentencing it is incum-bent on the judicial officer to take into account that, as noted above, any period of incarceration inevitably impacts more severely on the older offender.

The current legal position in South Africa as well as the three jurisdictions discussed above, seems to be ad idem on the following points: one, old age is not an excuse for committing a crime, but is an important factor in assessing the type and intensity/length of the punishment; two, under certain circumstances old age may be outweighed by other factors; three, 
the concept "old age" is determined by the courts depending on the circumstances of the offender in the light of other circumstances such as ill health. Thus "advanced age may be significant to, but not determinative of, the quantum of a sentence" ( $R$ v Kien (2000) 116 A Crim R 339 par [17]).

Marita Carnelley and Shannon Hoctor University of KwaZulu-Natal, Pietermaritzburg 